\title{
Modeling Of Control System for Hydrogen and Oxygen Gas Flow into PEMFC Based on Load Demand by Using Fuzzy Controller
}

\author{
Triyanto Pangaribowo $^{1 *}$,WahyuMulyo Utomo ${ }^{2}$, Afarulrazi ${ }^{3}$, Deni Shidqi Khaerudini ${ }^{4}$ \\ ${ }^{1}$ Department Of Electrical Engineering, Faculty Of Engineering, UniversitasMercuBuana, \\ Jakarta, Indonesia \\ ${ }^{2,3}$ Faculty Of Electrical And Electronic Engineering, Universiti Tun Hussein Onn Malaysia, Malaysia \\ ${ }^{4}$ Indonesian Institute Of Sciences, PuspitekSerpong,Tangerang, Indonesia \\ *Corresponding author E-mail:triyanto.pangaribowo@ mercubuana.ac.id
}

\begin{abstract}
This paper presents a control system to regulate the flow rate of hydrogen and oxygen gas for 500 watt PEMFC. Flow rates into the fuel cell are regulated according to load demand for fuel efficiency. Increase and decrease the rate of hydrogen flow according to the load demand, so this research proposes a feedback control system to supply load demand by regulating the fuel flow rate andfuel cell mathematical model.The proposed control algorithm for regulating the flow of hydrogen using the Mamdani Fuzzy method. The performance of the control system and the fuel cell model were tested with various loads. The simulation results show the fuzzy method has been able to regulate fuel cell output more effectively
\end{abstract}

Key words: Fuel cell, efficiency, simulation, fuzzy.

\section{INTRODUCTION}

PEM fuel cells is an electrochemical devices that are able to convert chemical energy into electrical energy that is environmentally friendly because it uses hydrogen and oxygen with heat and water as waste products [1]. Hydrogen has zero emissions so it can be stated as the cleanest fuel [2]. In fuel cell system, the stability of hydrogen pressure is very important for the performance of the whole system[3]. Starvation of fuel during PEMFC can produce serious damage that cannot be recovered. Large overpressure causes pinholes and reduces PEMFC performance to ensure safe PEM fuel cell operation[4]. Fuel savings can be done by dynamic control of hydrogen $(\mathrm{H} 2)$ concentrations while over-regulation of fuel pressure can affect durability and also for safe and efficient operation of fuel cells[5]. To maximize fuel efficiency, a recirculation loop recycles the anode outlet hydrogen back into the inlet[6].

The hydrogen fuel saving strategy can be carried out based on the load demand [7]. Fuel cell performance is influenced by several variables including reactant supply and load in transient conditions which can also affect fuel cell voltage levels[8]. Fluctuating loads are associated to important changes on the hydrogen requirement[9].Energy management in fuel cells is very important to increase fuel cell lifetime and also to minimize costs and minimum hydrogen consumption [10].
FOPID and fuzzy + PID have been developed to control PEMFC output voltage at the specified value by adjusting the mass flow rate of the hydrogen input[11].Previous research has proposed a PID control system which is usually used in the control of feedback voltage and feed flow control by manipulating the flow rate of air and hydrogen[12]. PID control has a simple structure and can adjust control parameters automatically to overcome system uncertainty and interference[13].The PID controller is used to adjust the pressure on the side of the PEFMC anode caused by load changes. [14]. In other studies it has been explained that the Fuzzy logic controller is able to control nonlinear and efficient systems without knowledge of the underlying dynamics and without using complex mathematical analysis[15].In some recent work, the Takagi-Sugeno paradigm has been successfully applied to PEM fuel cell systems to solve the problem of modeling, and fault diagnosis[16]. DC / DC converters are needed for power storage purposes but need to be controlled by the energy exchange between the storage device and the DC source due to different voltage levels [17].Fuzzy Logic as a decisionmaking algorithm is able to handle data ambiguity to get more valid [18]. Fuzzy controller work better than conventional PI controller to improve fuel cell performance following load changes[19].Hydrogen flow control with fuzzy methods has been presented but for power characteristics and control system performance not detailed discussed[20].In [21] ,fuzzy control has been proposed to control the flow of hydrogen for active power load variations, however, it does not discuss response time as one of the parameters for assessing the performance of the control system.Fuzzy PID control is more effective than the PID controller has been proposed to control the stack voltage but overshoot values are not discussed in detail[22].

This study proposes a more comprehensive discussion, from the mathematical model of PEMFC and also implements Fuzzy control on models that has been designed.This paper not only discusses the performance of fuzzy controls in terms of response time but also presents the characteristics of power, voltage and current generated by the fuel cell due to the regulation of hydrogen flow.In this study proposed a Mamdani Fuzzy controller to regulate hydrogen gas flow according to load demand. Mamdani Fuzzy controls are also nonlinear and compatible and provide stable performance under parameter variations and load interference. This research focuses on the critical problem of how to control 
the flow of hydrogen gas to the anode by using a fuzzy logic controller to get efficiencygas consumption. This study presents a PEM fuel cell dynamic and control system model. Then, explain the control strategy and simulate the system presented using the Matlab Simulink program.

\section{METODOLOGY}

This session presented thefuel cell working principle,fuel cell math equation, the proposed fuel cell dynamic model using Simulink,parameters used in the simulationand the Mamdani Fuzzy control strategy. For more detail discussed as follows

\subsection{Fundamental of Proton exchange membrane fuel cell} The reaction equation of a $\mathrm{PEMFC}$ is presented as;

$$
2 \mathrm{H} 2+\mathrm{O} 2 \rightarrow 2 \mathrm{H} 2 \mathrm{O}+\text { Heat }+ \text { Electricity }
$$

Based on equation (1), the reactans consist ofhydrogen $\left(\mathrm{H}_{2}\right)$ and oxygen $\left(\mathrm{O}_{2}\right)$ and produced water denotated by $\mathrm{HO}_{2}$. The reactions in electrodes are expressed as follows[23]

Anode $\quad: \mathrm{H}_{2} \rightarrow 2 \mathrm{H}^{+}+2 \mathrm{e}^{-}$

Cathode : $1 / 2 \mathrm{O}_{2}+2 \mathrm{H}+2 \mathrm{e}^{-} \rightarrow \mathrm{H}_{2} \mathrm{O}$

Herein, $+\mathrm{H}$ is the proton and $\mathrm{e}^{-}$denotes theelectron. A proton exchange membrane fuel cell (PEMFC) is a generator which converts hydrogen chemical energy into electrical energy [24]. This research focuses on regulating the flow of hydrogen gas at the anode based on load demand. The fuel cell system diagram is generally shown in figure 1 .

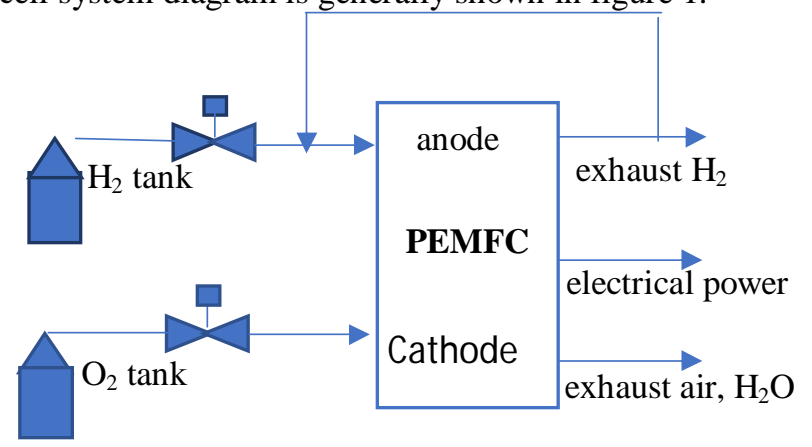

Figure 1: Schematic diagram of PEMFC system

\subsection{Mathematical modeling}

This case study uses PEMFC500 W. Fuel cell stack voltage is the multiplication of cell voltage with the number of cells (Ncell) stack with the following equation[25].

$$
V_{F C}=N_{\text {cell }}\left(E_{\text {Nernst }}-V_{\text {Act }}-V_{\text {Ohmic }}-V_{\text {Conc }}\right)
$$

Where $\mathrm{E}_{\mathrm{Nernst}}$ is the open circuit voltage, the ohmic voltage drop $\left(\mathrm{V}_{\mathrm{ohm}}\right)$, activation loss $\left(\mathrm{V}_{\text {act }}\right)$, concentration voltage drop $\left(\mathrm{V}_{\text {con }}\right)$. The Nernst equation is expressed using the ENernst thermodynamic potential [26] as follows

$$
E_{\text {Nernst }}=E^{0}+\frac{R T}{2 F}\left[\ln \left(P_{h_{2}}\right)+0.5 \ln \left(P_{o_{2}}\right)\right.
$$

where $\mathrm{E}^{0}$ is the reference potential at unit activity $(1.229 \mathrm{~V})$, $\mathrm{R}$ is the universal gas constant $(8.314 \mathrm{~J} /$ mole $\mathrm{K})$, and $\mathrm{F}$ denotes the Faraday's constant $(96,485$ C/mole). Concentration voltage losses that are computed by below equations[27]

$$
\begin{gathered}
V_{A c t}=-\left(\xi_{1}+\xi_{2} \cdot T+\xi_{3} \cdot T \cdot \ln \left(C o_{2}\right)\right) \\
+\xi_{4} \cdot T \cdot \ln \left(I_{F C}\right)
\end{gathered}
$$

where $\xi_{i}$ indicates semi-empirical coefficient. $\mathrm{I}_{\mathrm{FC}}(\mathrm{A})$ is the electrical current, and $\mathrm{C}_{\mathrm{O} 2}$ is the oxygen concentration[27]. $\mathrm{CO} 2$ is the concentration of dissolved oxygen at the liquid interface as defined by the Henry's law[24]

$$
C_{O_{2}}=\frac{P_{O_{2}}}{5.08 \times 10^{6} x e^{-\frac{498}{T}}}
$$

the ohmic voltage drop denoted by Vohmic. The Ohmic voltage drop in the cells is formulated [28] as follows

$$
\mathrm{V}_{\text {ohmic }}=\mathrm{I}_{\mathrm{FC}}\left(\mathrm{R}_{\mathrm{M}}+\mathrm{R}_{\mathrm{C}}\right)
$$

where $R_{C}(\Omega)$ is the contact resistance to electron flow, and $R_{M}(\Omega)$ is the resistance to proton transfer through the membrane, which can be described as follow

$$
R_{M}=\frac{\rho_{M} l}{A}
$$

where $\rho_{M}(\Omega \cdot \mathrm{cm})$ is the membrane specific resistivity, 1 $(\mathrm{cm})$ is the membrane thickness, $\mathrm{A}\left(\mathrm{cm}^{2}\right)$ is the membraneactive area[28],

$$
\rho_{M}=\frac{181.6\left[1+0.03\left(\frac{I_{F C}}{A}+0.062\left(\frac{T}{303}\right) 2\right]\right.}{\left[\psi-0.634-3\left(\frac{I_{F C}}{A}\right) \exp \left(4.18\left(T-\frac{303}{T}\right]\right.\right.}
$$

Where $\psi$ is a specific coefficient for every type of membrane; $V_{\text {con }}$ represents the voltage drop resulting from the mass transportation effects can be described by the following expression[29]

$$
V_{\text {Con }}=-B \cdot \ln \left(1-\frac{j}{j \max }\right)
$$

where B is a parametric coefficient, which depends on the cell and its operation state. $\xi \mathrm{i}$ indicates semi-empirical coefficient.j is the current $\operatorname{den} \operatorname{sity}\left(3 \mathrm{~mA} / \mathrm{cm}^{2}\right)$ and $\mathrm{j}_{\max }$ is the maximum current density $(469 \mathrm{~mA} / \mathrm{cm} 2)$. Output current of the fuel cell by adjusting the feed gas flow rates as follows.

$$
\frac{i}{2 F}=\frac{q_{h_{2 \text { in }}} * q_{o_{2} \text { in }}}{R T}
$$

Relation between molar flow $\mathrm{qH}_{2}$ and partial pressure $\mathrm{PH}_{2}$ for hydrogen gas expressed as follows

$$
K_{\mathrm{H}_{2}}=\frac{q \mathrm{H}_{2}}{\mathrm{PH_{2 }}}=\frac{k_{a n}}{\sqrt{\mathrm{MH}_{2}}}
$$

$\mathrm{KH}_{2}$ is hydrogen valve molar constant, $\mathrm{MH}_{2}$ is molar mass of hydrogen and $\mathrm{k}_{\mathrm{an}}$ is anode valve constant. The reacted hydrogen flow for a fuel cell stack is shown by the following equation[19]:

$$
q_{H_{2}}^{r}=\frac{N_{0} I}{2 F}=2 K_{r}
$$

Where $N_{o}$ is the number of fuel cells , I is fuel stack current, $\mathrm{K}_{\mathrm{r}}$ is modelling constant. By using the Laplace transform for hydrogen partial pressure is determined by the following equation[30]:

$$
P_{\mathrm{H}_{2}}=\frac{1 / K_{\mathrm{H}_{2}}}{1+\tau \mathrm{H}_{2} \mathrm{~S}}\left(q_{\mathrm{H}_{2}}^{i n}-2 K_{r} I\right)
$$

Where hydrogen time constant $\tau \mathrm{H}_{2} \mathrm{~S}$ is given by[30]

$$
\tau_{H_{2}}=\frac{V_{a n}}{K_{H_{2}} R T}
$$

According to Faraday's law, the reacted oxygen flow $q_{O_{2}}^{r}$ can be written as:

$$
q_{O_{2}}^{r}=\frac{N_{0}}{4 F}=K_{r} I
$$

The oxygen partial pressure at cathode can also be calculated by equation[31]:

$$
P_{O_{2}}=\frac{1 / K_{O_{2}}}{1+\tau_{O_{2}}}\left(q_{O_{2}}^{i n}-K_{r} I\right)
$$

The oxygen time constant $\tau o_{2}$ is expressed as[31]

$$
\tau o_{2}=\frac{V_{a n}}{K o_{2} R T}
$$

According to electrochemical relationships, a relationship between the stack current and the molar flow of hydrogen can be written as[21] 


$$
q_{H_{2}}=\frac{N_{0} I_{\text {stack }}}{2 F U}
$$

WhereU is a utilization factor. $K o_{2}$ is oxygen valve molar constant and $q_{\mathrm{O}_{2}}^{\text {in }}$ is oxygen input flow. Parameter identification of PEFMC [32]for this study use approach BCS $500 \mathrm{~W}$ with number of cell 32.

Table 1:Parameters used in the simulation.

\begin{tabular}{|l|l|l|c|}
\hline Symbol & Parameters & \multicolumn{1}{c|}{ Value } & Unit \\
\hline $\mathrm{P}$ & Rated power & 500 & $\mathrm{~W}$ \\
\hline $\mathrm{N}_{\text {cell }}$ & Number of cells & 32 & - \\
\hline $\mathrm{A}$ & Area & 64 & $\mathrm{~A}\left(\mathrm{~cm}^{2}\right)$ \\
\hline $\mathrm{L}$ & Length & 178 & $(\mu \mathrm{m})$ \\
\hline $\mathrm{Jn}$ & Current density & 469 & $(\mathrm{~mA} / \mathrm{cm} 2)$ \\
\hline $\mathrm{Jmax}$ & Current density & 3 & $(\mathrm{~mA} / \mathrm{cm} 2)$ \\
\hline $\mathrm{T}(\mathrm{K})$ & Temperature & 333 & $\mathrm{~K}$ \\
\hline$\xi_{1}$ & $\begin{array}{l}\text { Parametric } \\
\text { coefficients }\end{array}$ & -0.948 & - \\
\hline$\xi_{2}$ & $\begin{array}{l}\text { Parametric } \\
\text { coefficients }\end{array}$ & $\begin{array}{l}2.315 \times 10 \\
-3\end{array}$ & - \\
\hline$\xi_{3}$ & $\begin{array}{l}\text { Parametric } \\
\text { coefficients }\end{array}$ & $\begin{array}{l}7.6 \\
\times 10-5\end{array}$ & - \\
\hline$\xi_{4}$ & $\begin{array}{l}\text { Parametric } \\
\text { coefficients }\end{array}$ & 1.93 \\
$\times 10-5$ & - \\
\hline$\psi$ & $\begin{array}{l}\text { Parametric } \\
\text { coefficients }\end{array}$ & 23 & - \\
\hline $\mathrm{R}_{\mathrm{C}}$ & $\begin{array}{l}\text { Parametric } \\
\text { coefficients }\end{array}$ & 0.0003 & - \\
\hline $\mathrm{B}$ & $\begin{array}{l}\text { Parametric } \\
\text { coefficients }\end{array}$ & 0.066 & - \\
\hline
\end{tabular}

\subsection{ModelingOfcontrol system}

According to the mathematical equations above, the PEMFC control model was developed in the Matlabsimulink. The control system uses the fuzzy method to adjust the hydrogen flow rate based on load demand. The flow rate control scenario follows the load demand for fuel savings. If the maximum flow rateof hydrogen gas is given constantly then fuel consumption becomes very high. For more details, the design of the fuzzy control system is shown in the figure 2.

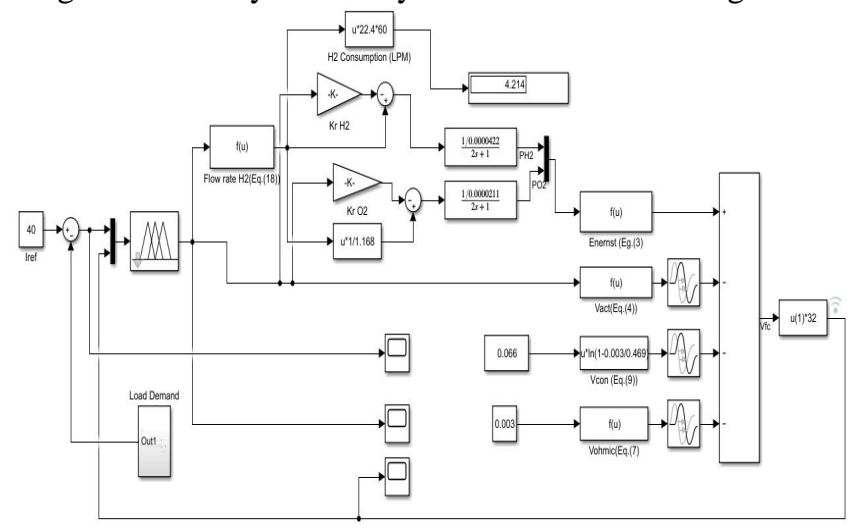

Figure 2:PEM fuel cell system dynamic model and fuzzy control

The model in figure 2 includes the PEM model and the fuzzy controller. Figure 2 shows the fuzzy mamdani control strategy for hydrogen flow is applied to the dynamic PEMFC model. Fuzzy system has two inputs consisting of error and output voltage of PEMFC. Where error is the reference current minus load demand. The PEMFC model uses hydrogen valve constant is $4.22 * 10^{-5} \mathrm{Kmol}(\mathrm{atms})^{-1}$ and oxygen valve constant is $2.11 * 10-5 \mathrm{Kmol}(\mathrm{atms})-1$. Hydrogen and oxygen time constant are 2 seconds.

Mamdani Fuzzy control[33] in this study uses the centroid method with the following equations:

$$
z=\frac{\sum_{j=i}^{n} z_{j} \mu\left(z_{j}\right)}{\sum_{j=i}^{n} \mu\left(z_{j}\right)}
$$

The membership function equation of the two input variables is shown as follows:

$$
\begin{aligned}
& \mu L(x)=\left\{\begin{array}{c}
0 ; x \leq 0 \\
\frac{10-x}{10} ; 0<x<10 \\
0 ; x \geq 10
\end{array}\right. \\
& \mu M(x)=\left\{\begin{array}{c}
\frac{x-8}{7} ; 8<x<15 \\
\frac{22-x}{7} ; 15 \leq x<22
\end{array}\right. \\
& \mu H(x)=\left\{\begin{array}{r}
0 ; x \leq 20 \\
\frac{x-20}{10} ; 20<x<30 \\
0 ; x \geq 30
\end{array}\right.
\end{aligned}
$$

The membership function equation of output variable is shown as follows:

$$
\begin{gathered}
\mu V L(x)=\left\{\begin{array}{c}
0 ; x \leq 0 \\
\frac{6-x}{6} ; 0<x<6 \\
0 ; x \geq 6
\end{array}\right. \\
\mu L(x)=\left\{\begin{array}{l}
\frac{x-6}{4} ; 6<x \leq 9 \\
\frac{12-x}{3} ; 9<x<12
\end{array}\right. \\
\mu M(x)=\left\{\begin{array}{l}
\frac{0 ; x \leq 12}{\frac{x-12}{3} ; 12<x \leq 15} \\
\frac{18-x}{3} ; 15<x<18
\end{array}\right. \\
\mu \mu H(x)=\left\{\begin{array}{l}
0 ; x \leq 18 \text { and } x \geq 24 \\
\frac{x-18}{3} ; 18<x \leq 21 \\
\frac{24-x}{3} ; 21<x<24
\end{array}\right. \\
\mu \mu V H(x)=\left\{\begin{array}{c}
\frac{x-24}{5} ; 20<x<30 \\
0 ; x \geq 30
\end{array}\right.
\end{gathered}
$$

The type of fuzzy inferenceengine using Mamdani. Variables input of fuzzy set consist of $\operatorname{low}(\mathrm{L})=\left[\begin{array}{ll}0 & 10\end{array}\right]$, middle $(\mathrm{M})=\left[\begin{array}{ll}8 & 22\end{array}\right]$ and $\operatorname{high}(\mathrm{H})=\left[\begin{array}{ll}20 & 30\end{array}\right]$. Fuzzy set for output variables consist of very $\operatorname{low}(\mathrm{VL})=\left[\begin{array}{ll}0 & 6\end{array}\right], \operatorname{low}(\mathrm{L})=[6$ 12], middle $(\mathrm{M})=\left[\begin{array}{ll}12 & 18\end{array}\right]$, high $(\mathrm{H})=\left[\begin{array}{ll}18 & 24\end{array}\right]$, and very high $(\mathrm{VH})=\left[\begin{array}{ll}24 & 30\end{array}\right]$. 


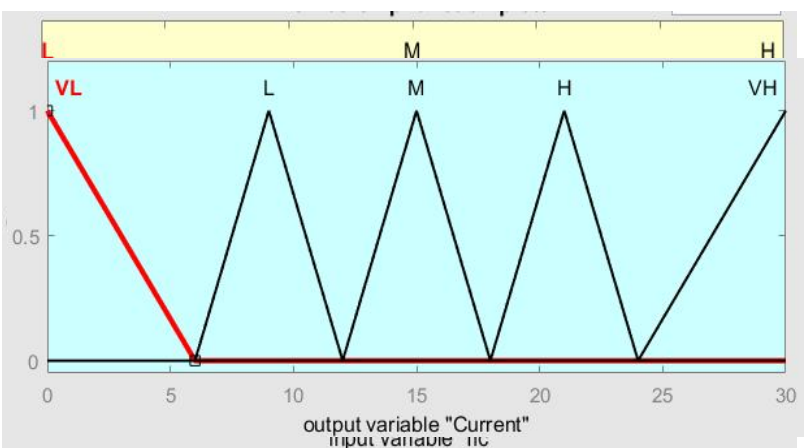

(b)

Figure 3: (a) Membership function of inputvariable;

(b) Membership function of output variable

The membership functions for input load are feedback from PEMFC output voltage and reference current minus current load demand called error. Fuzzy control rule base is shown in Table. 3 usingfuzzy Mamdani. The centroid method is used for defuzzification

Table 2: Linguistic control rule

\begin{tabular}{|c|c|c|c|}
\hline \multirow{2}{*}{$\begin{array}{c}\text { Voltage } \\
\text { feedback }\end{array}$} & \multicolumn{3}{|c|}{ Error } \\
\cline { 2 - 4 } & $\mathrm{L}$ & $\mathrm{M}$ & $\mathrm{H}$ \\
\hline $\mathrm{L}$ & $\mathrm{VL}$ & $\mathrm{L}$ & $\mathrm{M}$ \\
\hline $\mathrm{M}$ & $\mathrm{L}$ & $\mathrm{M}$ & $\mathrm{H}$ \\
\hline $\mathrm{H}$ & $\mathrm{M}$ & $\mathrm{H}$ & $\mathrm{VH}$ \\
\hline
\end{tabular}

\section{RESULTS AND DISCUSSION}

Performance characteristics of the stack are presented based on simulation result.The curve in figure 4 . is obtained by giving a current feed to the fuel cell model dynamics starting from $1 \mathrm{~A}$ up to $30 \mathrm{~A}$ by increasing the current $1 \mathrm{~A}$ for each step.For a minimum current input of $1 \mathrm{~A}$ produces an output voltage of $23.77 \mathrm{~V}$ and for a maximum current of $30 \mathrm{~A}$ produces a fuel cell output $19.12 \mathrm{~V}$

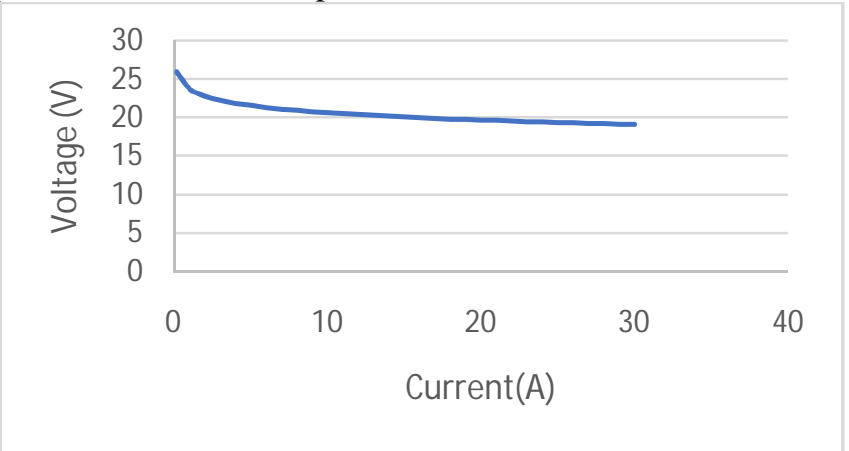

Figure 4: Characteristic curve of a fuel cell

Figure 4 is a curve from the simulation results that has shown the relationship of voltage and current for PEMFC.The polarization curve test of fuel cell stack was conducted under a constant temperature condition. Figure 5 shows the characteristic curve of the power and current relationship

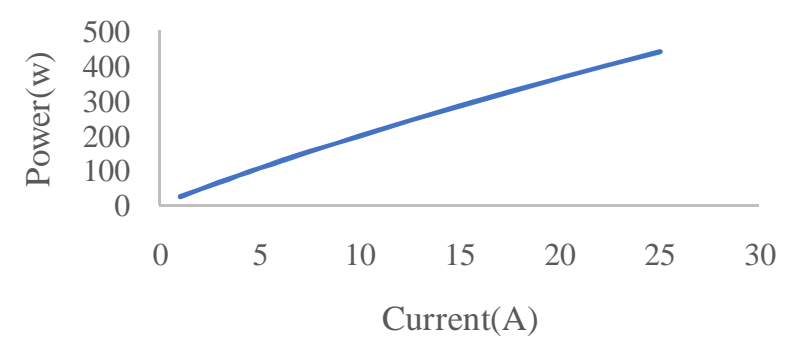

Figure 5:characteristic curve between power and current.

The curve of the relationship between power and current is obtained using the power formula which is expressed as follows

$$
P_{\text {stack }}=V_{\text {stack }} x I_{\text {stack }}
$$

Power has been calculated based on the data in figure 4.The simulation results show that the maximum power produced by the fuel cell is 574 watts.Figure 6 is obtained using equation (18) which shows the relationship between current and flow of hydrogen. The flow of hydrogen gas is increased every step of 0.28 LPM until it reaches 8.3 LPM. Simulation results show that for a minimum flow of hydrogen gas 0.28 LPM produces $23.77 \mathrm{~W}$ of power and for a maximum gas flow of 8.3 LPM produces 574 Watt.More detail for the relationship between power and hydrogen gas consumption is shown in the figure 6 .

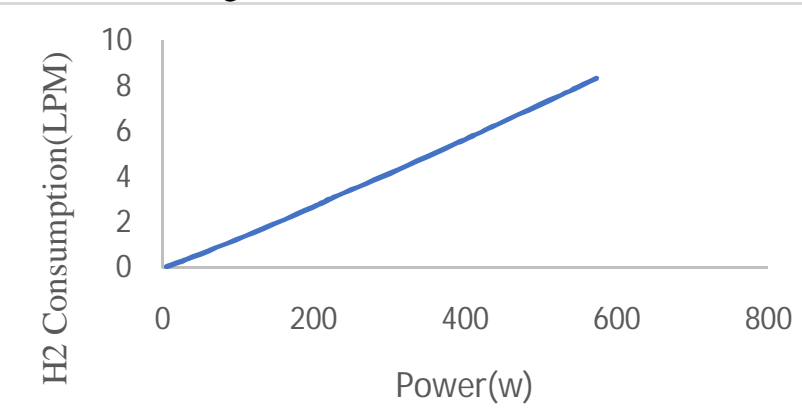

Figure 6:Characteristic polarization curve of hydrogen consumption

Figure 7 shows the time response between fuzzy controller and uncontrolled. The fuzzy control system using a reference currentof $40 \mathrm{~A}$ and a current load of $15 \mathrm{~A}$,so it has an error of $25 \mathrm{~A}$. The error current of $25 \mathrm{~A}$ is fed to the fuzzy control as input. For uncontrolled systems using the samefuzzy control with input current is $25 \mathrm{~A}$. The target fuel cell output voltage is $19.37 \mathrm{~V}$. Based on simulation result for response time of fuzzy control to produce fuel cell output voltage of $19.37 \mathrm{~V}$ is about $2.4 \mathrm{~s}$ and for uncontrolled $8.8 \mathrm{~s}$. Fuzzy control has been able to improve good response time performance. The maximum output voltage generated by the fuel cell with fuzzy control has been able to increase from $19.37 \mathrm{~V}$ up to 19.61V. For more details shown in the picture 7.

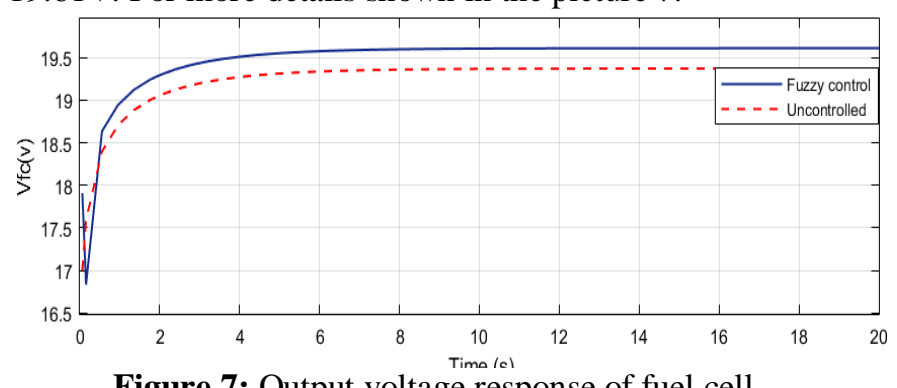

Figure 7: Output voltage response of fuel cell 
The loadcurrent changing depends on the type of the external electrical load. In the simulations, there are three current load variables namely $15 \mathrm{~A}, 20 \mathrm{~A}$ and $25 \mathrm{~A}$. The load changes every 4 seconds. For more detailsload changes are shown in the figure 8 .

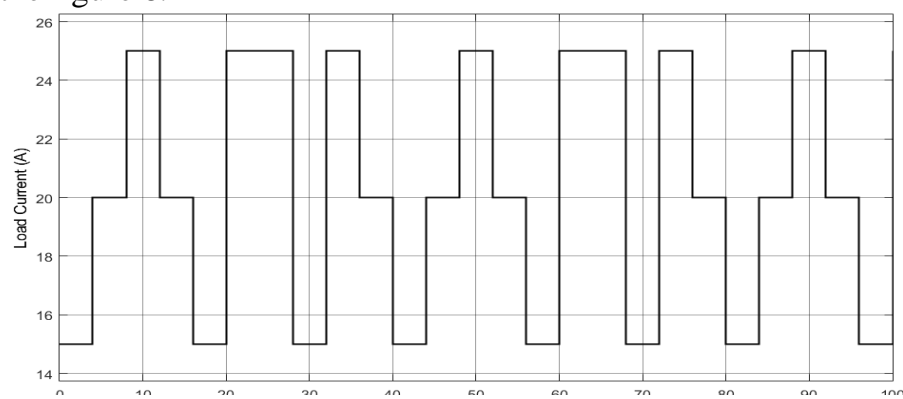

Figure 8: Variation of load current

Figure 9 is a graph of the consumption of hydrogen and oxygen gas by the fuel cell according to load demand.

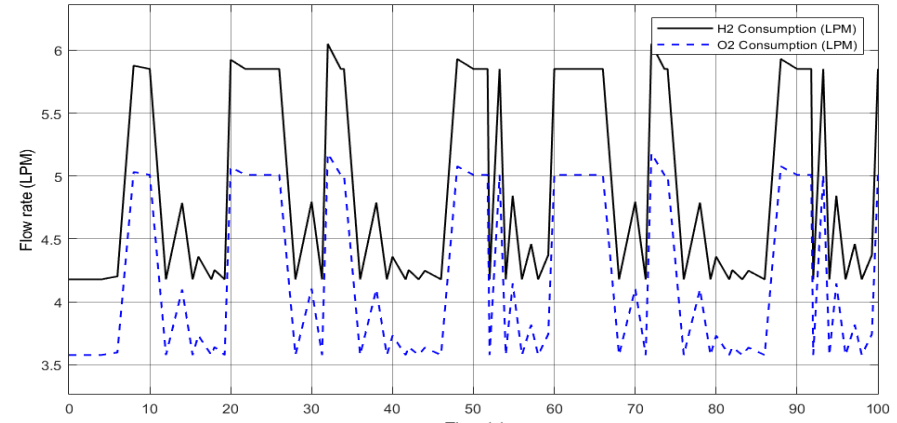

Figure 9:Regulation of hydrogen and oxygen consumption with fuzzy control

Theflow ratio between hydrogen and oxygen gas for this study is 1.168. Figure 10 shows the hydrogen flow rate between fuzzy and uncontrolled. For the same current load variable shows fuzzy control is able to control flow effectively. Fuzzy is able to regulate hydrogen flow so that the increase in gas consumption can be reduced.The simulation was done with thetime duration of 100 seconds. The maximum load used in this simulation is $25 \mathrm{~A}$ according to figure 8 . Average hydrogen consumption with fuzzy is 1.1 LPM more efficient than uncontrolled for 25A loadin other words average hydrogen flow for fuzzy 5.85 LPM and for the uncontrolled 6.96 LPM.

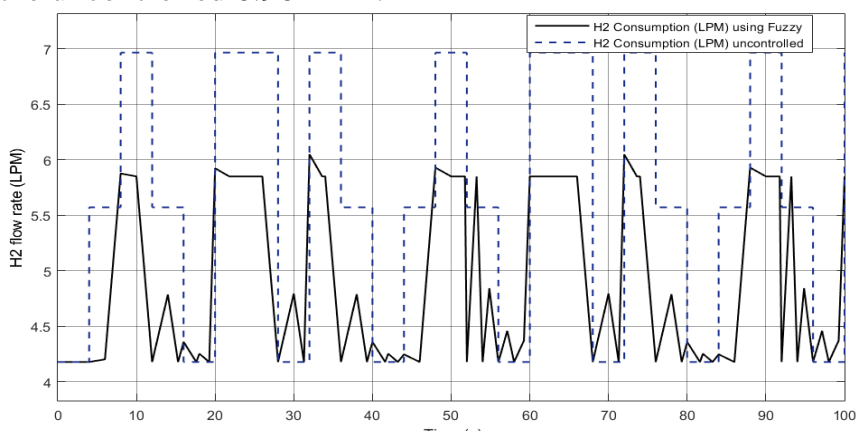

Figure 10: Hydrogen and oxygen flow ratio

\section{CONCLUSIONS}

In this research, a performance investigation for the dynamic model of PEM fuel cell systems and fuzzy control in regulating the flow rate of hydrogen to PEMFC was carried out. The results of the dynamic fuel cell model test by raising the current feed to the fuel cell have shown satisfactory results. Based on the dynamic model the fuel cell has produced maximum power in accordance with the target range set at $\mathbf{5 7 4}$ watts.Likewise for hydrogen flow rates are still within the target range of 8.36 LPM.Fuzzy control works well for suddenly changing loads.Fuzzy control has good performance with no overshoot and has a response time of 2.4 seconds to reach the target fuel cell output voltage of $19.37 \mathrm{~V}$. Fuzzy control was able to reduce the average hydrogen consumption of 1.1 LPM for a current load of $25 \mathrm{~A}$ which was tested for 100 seconds rather than uncontrolled.

\section{REFERENCES}

1. S. Hanapi, A. S. Tijani, A. H. A. Rahim, and W. A. N. W. Mohamed, Exergy Efficiency Profile of A $1 k W$ Open Cathode Fuel Cell with Pressure and Temperature Variations, vol. 79. Elsevier B.V., 2015.

2. M. K. Singla, A. S. Oberoi, and P. Nijhawan, "Trends so far in hydrogen fuel cell technology: State of the art," Int. J. Adv. Trends Comput. Sci. Eng., vol. 8, no. 4, pp. 1146-1155, 2019.

3. X. Ye, T. Zhang, H. Chen, J. Cao, and J. Chen, "Fuzzy control of hydrogen pressure in fuel cell system," Int. J. Hydrogen Energy, vol. 44, no. 16, pp. 8460-8466, 2019.

4. Y. Zhu, J. Zou, C. Peng, Y. Xie, and L. Li, "Modelling and fuel flow control of PEMFC considering overpressure case," Proc. - 2017 Chinese Autom. Congr. CAC 2017, vol. 2017-Janua, pp. 2222-2225, 2017.

5. A. Ebadighajari, J. Devaal, and F. Golnaraghi, "Multivariable control of hydrogen concentration and fuel over-pressure in a polymer electrolyte membrane fuel cell with anode re-circulation," Proc. Am. Control Conf., vol. 2016-July, pp. 4428-4433, 2016.

6. B. Wu, M. Matian, and G. J. Offer, "Hydrogen PEMFC system for automotive applications," Int. J. LowCarbon Technol., vol. 7, no. 1, pp. 28-37, 2012.

7. N. Bizon, "Fuel saving strategy using real-time switching of the fueling regulators in the proton exchange membrane fuel cell system," Appl. Energy, vol. 252, no. June, p. 113449, 2019.

8. A. Morán-Durán, A. Martínez-Sibaja, J. P. RodríguezJarquin, R. Posada-Gómez, and O. S. González, "PEM fuel cell voltage neural control based on hydrogen pressure regulation," Processes, vol. 7, no. 7, 2019. https://doi.org/10.3390/pr7070434

9. A. C. Rojas, G. L. Lopez, J. F. Gomez-Aguilar, V. M. Alvarado, and C. L. S. Torres, "Control of the air supply subsystem in a PEMFC with balance of plant simulation," Sustain., vol. 9, no. 1, pp. 1-23, 2017.

10. H. Marzougui, A. Kadri, M. Amari, and F. Bacha, "Improvement of energy management algorithm for fuel cell electrical vehicle with fuzzy logic," 2017 18th Int. Conf. Sci. Tech. Autom. Control Comput. Eng. STA 2017 - Proc., vol. 2018-Janua, pp. 212-217, 2018.

11. Y. Qi, M. Thern, M. Espinoza-Andaluz, and M. Andersson, "Modeling and Control Strategies of Proton Exchange Membrane Fuel Cells," Energy Procedia, vol. 159, pp. 54-59, 2019.

12. W. R. W. Daud, R. E. Rosli, E. H. Majlan, S. A. A. Hamid, R. Mohamed, and T. Husaini, "PEM fuel cell system control: A review," Renew. Energy, vol. 113, pp. 620-638, 2017.

13. H. Cao and X. Li, "Thermal Management-Oriented Multivariable Robust Control of a kW-Scale Solid 
Oxide Fuel Cell Stand-Alone System," IEEE Trans. Energy Convers., vol. 31, no. 2, pp. 596-605, 2016.

14. Y. Li, X. Zhao, S. Tao, Q. Li, and W. Chen, "Experimental Study on Anode and Cathode Pressure Difference Control and Effects in a Proton Exchange Membrane Fuel Cell System," Energy Technol., vol. 3, no. 9, pp. 946-954, 2015.

15.M. S. AbouOmar, H. J. Zhang, and Y. X. Su, "Fractional order fuzzy PID control of automotive PEM fuel cell air feed system using neural network optimization algorithm," Energies, vol. 12, no. 8, 2019.

16. D. Rotondo, F. Nejjari, and V. Puig, "Fault tolerant control of a proton exchange membrane fuel cell using Takagi-Sugeno virtual actuators," J. Process Control, vol. 45, pp. 12-29, 2016.

17. K. Kaya and Y. Hames, "Two new control strategies: For hydrogen fuel saving and extend the life cycle in the hydrogen fuel cell vehicles," Int. J. Hydrogen Energy, vol. 44, no. 34, pp. 18967-18980, 2019.

18. O. R. Devi, "International Journal of Advanced Trends in Computer Science and Engineering Available Online at http://www.warse.org/ijatcse/static/pdf/file/ijatcse024220 15.pdf," vol. 4, no. 2, pp. 15-21, 2015.

19. A. K. Saha, S. P. Chowdhury, S. Chowdhury, and Y. H. Song, "Dynamic model of PEM fuel cell with fuzzy logic controller," Proc. Univ. Power Eng. Conf., no. 1, pp. 753-757, 2007.

20. S. E. E. Profile and S. E. E. Profile, "Hydrogen flow control by using fuzzy logic controller method for fuel cell power systems," no. September 2017, 2014.

21. K. Mammar and A. Chaker, "Fuzzy logic-based control of power of PEM fuel cell system for residential application," Leonardo J. Sci, no. 14, pp. 147-166, 2009.

22. W. Xia and Z. Qi, "Dynamic modeling and fuzzy PID control study on proton exchange membrane fuel cell," 2010 2nd Conf. Environ. Sci. Inf. Appl. Technol. ESIAT 2010, vol. 3, no. 7, pp. 116-119, 2010.

23. P. Buasri and Z. M. Salameh, "An electrical circuit model for a Proton Exchange Membrane Fuel Cell (PEMFC)," 2006 IEEE Power Eng. Soc. Gen. Meet. PES, no. 4, 2006.

24. K. Ou, Y. X. Wang, Z. Z. Li, Y. De Shen, and D. J. Xuan, "Feedforward fuzzy-PID control for air flow regulation of PEM fuel cell system," Int. J. Hydrogen Energy, vol. 40, no. 35, pp. 11686-11695, 2015.

25. F. Zhang, K. Thanapalan, A. Procter, J. Maddy, and A. Guwy, "Fuzzy logic control for solar powered hydrogen production, storage and utilisation system BT - 2012 UKACC International Conference on Control, CONTROL 2012, September 3, 2012 September 5, 2012," no. September, pp. 912-917, 2012.

26. F. Grumm, M. Schumann, C. Cosse, M. Plenz, A. Lücken, and D. Schulz, "Short circuit characteristics of PEM fuel cells for grid integration applications," Electron., vol. 9, no. 4, pp. 1-18, 2020. https://doi.org/10.3390/electronics9040602

27. H. C. Nejad, M. Farshad, E. Gholamalizadeh, B. Askarian, and A. Akbarimajd, "A novel intelligentbased method to control the output voltage of Proton Exchange Membrane Fuel Cell," Energy Convers. Manag., vol. 185, no. February, pp. 455-464, 2019.

28. Y. Cao, Y. Li, G. Zhang, K. Jermsittiparsert, and N. Razmjooy, "Experimental modeling of PEM fuel cells using a new improved seagull optimization algorithm," Energy Reports, vol. 5, no. November, pp. 1616-1625, 2019.

29. F. Liping, L. Yi, and L. Chong, "Fuzzy Logic based Constant Voltage Control of PEM Fuel Cells," TELKOMNIKA Indones. J. Electr. Eng., vol. 10, no. 4, pp. 612-618, 2012.

30. S. M. Rakhtala and E. Shafiee Roudbari, "Fuzzy PID control of a stand-alone system based on PEM fuel cell," Int. J. Electr. Power Energy Syst., vol. 78, pp. 576590, 2016.

31. M. Abdullah and M. Idres, "Constrained model predictive control of proton exchange membrane fuel cell," J. Mech. Sci. Technol., vol. 28, no. 9, pp. 38553862, 2014.

32. Y. Rao, Z. Shao, A. H. Ahangarnejad, E. Gholamalizadeh, and B. Sobhani, "Shark Smell Optimizer applied to identify the optimal parameters of the proton exchange membrane fuel cell model," Energy Convers. Manag., vol. 182, no. September 2018, pp. 1-8, 2019.

33. A. Saleh, Fujiati, R. Rosnelly, K. Puspita, and A. Sanjaya, "A comparison of Mamdani and Sugeno method for optimization prediction of traffic noise levels," 2017 5th Int. Conf. Cyber IT Serv. Manag. CITSM 2017, pp. 5-8, 2017. 